\title{
The rehabilitation of a reservoir: A new methodological approach for calculating the sustainable useful storage capacity
}

\author{
Annamaria De Vincenzo ${ }^{1}$, Bruno Molino $^{2^{\star}}$ \\ ${ }^{1}$ School of Engineering, University of Basilicata, Potenza, Italy \\ ${ }^{2}$ Department of Agricultural, Environmental and Food Sciences, University of Molise, Campobasso, Italy; \\ *Corresponding Author: bruno.molino@unimol.it
}

Received 28 May 2013; revised 25 June 2013; accepted 10 July 2013

Copyright (C) 2013 Annamaria De Vincenzo, Bruno Molino. This is an open access article distributed under the Creative Commons Attribution License, which permits unrestricted use, distribution, and reproduction in any medium, provided the original work is properly cited.

\begin{abstract}
Present work introduces the sustainable useful storage capacity as the minimum storage capacity able to satisfy the water demand for drinkable, industrial and irrigational purposes and necessary in order to overcome water deficit situations which, at least in Central Southern Italy, occur in the summer, when agricultural demand is really high. Sediment volumes to be removed from the reservoir bottom will be calculated as the difference between the current and the sustainable useful storage capacities of the reservoir in study. The calculation methodology of the useful sustainable storage capacity, based on the reservoir water balance between inflows at the reservoir and water demand, has been applied to the Camastra reservoir (Basilicata, Southern Italy), for which numerous reliable data including more than $\mathbf{4 0}$ years of inflows and water supplied volumes and data relative to 7 bathymetric surveys are available. Result analysis shows that this methodology, at least in the study case, enables sediment quantities to be removed more sustainably from a technical, economical and environmental point of view.
\end{abstract}

Keywords: Reservoir Sedimentation; Water Demand and Emergencies; Water Balance; Useful Storage Capacity; Reservoir Sediment Reuse

\section{INTRODUCTION}

A dam impacts on the normal flow of water, creating an upstream area with low water velocity and conse- quently high sedimentation levels of sediments transported by the current. Over time these sediments lead to a reduction in the initial storage capacity of the reservoir bringing its progressive silting up. Because of their presence close to the dam these sediments could, in the course of time, also constitute an impediment to the normal functioning of reservoir outlets for reservoir management as well as for control of floods $([1,2])$.

The national regulatory framework concerning the management of sediments is made up of a series of laws, including laws 319/76, 183/89, 36/94, 152/99, D.M.30/ 06/2004, 152/06 and the Environment Ministry Decree n.161/2012, concerning the utilization of excavated earth and rocks, which provide precise technical and organizational means for the safeguarding of waters and for the defense of the soil, as well as for the management of water resources and reservoir sedimentation.

Article 40, paragraph 2, of Decree Law 152/99 introduces the obligation on the part of dam management to draw up a "Management Project".

The decree laws (still in force) necessary for the activation of the management projects were disciplined by the decree of 30.06.2004.

The successive Decree Law 152/06, which is, at the moment, the only operative tool supporting the drawing up of management plans, once again highlighted the necessity for intervention on the question of the management of these plants.

Specifically, article 114 of D. Law 152/06, which replaced art. 40 of D. Law 152/99 now abrogated, states that actions dealing with sediment in reservoirs should be carried out on the basis of a management project specific for each reservoir which must:

- "Ensure the maintenance of reservoir capacity" (para- 
graph 2) through operations including draw-down, dredging and flushing of the reservoirs which are environmentally sustainable and which do not impact negatively on the river downstream from the reservoir;

- "Define the envisaged activity framework of these operations", which must also guarantee the functioning of dam outlets and intakes.

Basically the Management Project should provide a detailed framework of envisaged activities including operations draw-down, dredging and flushing connected with plant maintenance; it will also include an activities schedule and a description of the operating procedures which the dam manager intends to utilize for the removal of sediments and also its end use with the aim of restoring the original reservoir capacity within the concession deadline.

Reservoir management agencies are thus responsible, according to the regulations in force, for the removal of sediments, which, except in a limited number of cases, are unsustainable in terms of quantity for the objective technical and economic difficulties posed by sediment removal operations and reuse ([3-5]).

The problem of the lack of sustainability with regard to the restoration of the original useful capacity of reservoirs is particularly marked for the majority of Italian reservoirs under public management in central-southern Italy. Here, they usually have significant quantities of sediment to deal with, lack of funds and technical, economic and environmental difficulties associated with sediment disposal whereas lack of sustainability is only marginally relevant for the hydro-electric plants in the Alpine and pre-Alpine areas where, not surprisingly, most of the management projects which have already been presented, are located ([6,7]). The question of sustainability becomes increasingly problematic, the greater the ratio between existing levels of silting up and the dead volume foreseen in the project. This ratio increases when the annual average rate of silting up phenomena differs from the constant average rate envisaged in the project for the first decades of the plant life, for reasons which are often not the responsibility of reservoir management Authority, such as absence of or delay in river training works, modification in upstream land use (new productive activities and consequent variations from transported sediments to the river network), development of landslide phenomena, etc.

The aim of the work is to propose a new methodology for the computation of sustainable volumes of sediments to be removed of the related sustainable useful storage capacity. The proposed methodology takes into account the users water demand rather than the restoration of the original useful storage capacity imposed by law.

\section{METHODOLOGY OF CALCULATION}

The calculation methodology of useful sustainable capacity is founded on the analysis of monthly reservoir water balance between inflows at the reservoir and water demand, calculated on the basis of water volumes historically supplied to reservoir users.

Inflows to the reservoir are calculated on the basis of data annually elaborated by the reservoir management Authority, from which it is possible to deduce for each year the annual and monthly inflows by applying the continuity equation to the storage. A successive statistical elaboration ([8-11]) of the monthly inflows permits the definition of laws of variation in the average monthly inflow as a function of cumulative probability $\varphi$ and, thus, of the return period $T$. Figure 1 (where letters on $\mathrm{x}$ axis are for the months of year) shows, for example, the average monthly inflow $I$ as a function of $T$ at the Camastra Dam (Basento River, Southern Italy).

The average monthly water volume supplied to users $U$ is also obtainable from historical data provided by the reservoir management Authority and varies according to the final utilization of the water resource (drinkable, industrial and irrigational uses). Between users the proposed methodology also takes into account the water course downstream from the dam which requires a minimum ecological discharge for its conservation. Many methods for the calculation of minimum ecological discharge are available in the technical and scientific literature ([12-24]).

A monthly reservoir water balance between average monthly inflows I, corresponding to a given return period, and water volumes monthly supplied to users $U$ and released for the river ecological preservation $E$, which are constant in relation to the return period, permits the calculation of the volumes $W$ stored in the reservoir for each month and for different return period according to the equation:

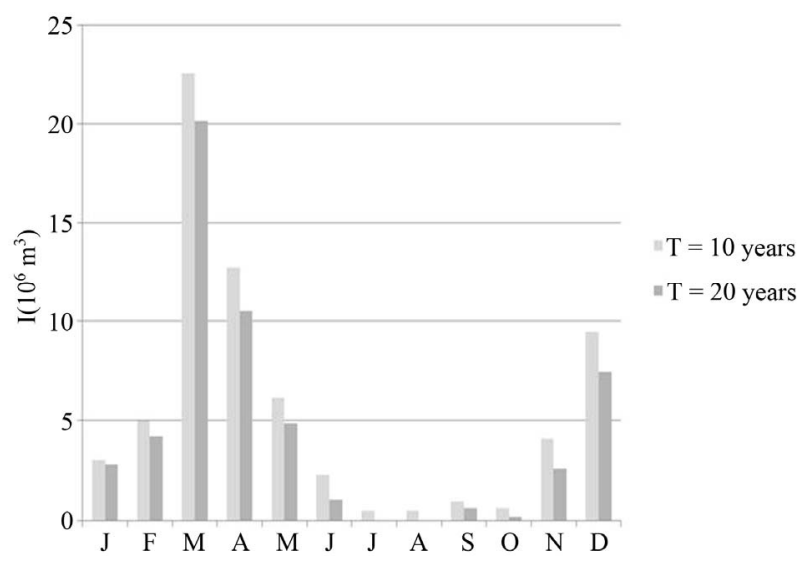

Figure 1. Average monthly inflows from January $(\mathrm{J})$ to December (D) as a function of return period. 


$$
W=I-U-E
$$

where

$$
U=U_{\text {drink }}+U_{\text {ind }}+U_{\text {irr }}
$$

$U_{\text {drink }}, U_{\text {ind }}$ and $U_{\text {irr }}$ are the water volume supplied for drinkable, industrial and irrigational purposes, respectively.

If industrial and irrigation water supplies are carried out, as usual, via stream bed discharge, like the minimum ecological discharge, for each return period and each month the stored volumes $\mathrm{W}$ are the result of the operation

$$
W=I-U_{\text {drink }}-U_{\text {ind }}-U_{\text {irr }}-R
$$

where $R$ represent the instream releases dowstream from the dam. The releases $R$ will be equal to:

$E$ in the months when $\left(U_{\text {ind }}+U_{\text {irr }}\right)=0$;

$\left(U_{\text {ind }}+U_{\text {irr }}\right)$ in the months when $\left(U_{\text {ind }}+U_{\text {irr }}\right)$ is greater than $\mathrm{E}$;

$\left(E-U_{\text {ind }}-U_{\text {irr }}\right)$ in the months when $\left(U_{\text {ind }}+U_{\text {irr }}\right)$ is lower than $E$.

Positive stored volumes indicate higher inflows with respect to supplied volumes, whereas negative stored volumes signify a deficit condition. The reservoir water balance expressed by the relation (1) or (3) thus permits the identification of possible periods of water deficit in accordance with return period variation. In Italy the deficit months fall usually under the summer season, when water demand is greater than reservoir inflows. For each return period the sum of the stored water volumes in the deficit months represents the deficit volume $W_{d}(T)$. If the deficit volume $W_{d}(T)$ is lower than the reservoir current useful capacity $C$, which depends on the level of silting up which the reservoir under study has experienced over time, the current useful capacity is able to overcome the water emergencies with a return period $T$ without any desiltation, dredging or sediment removing operations. If otherwise $W_{d}(T)>C$ will be necessary to remove sediments from the reservoir bottom. The minimum sediment volume $V_{s}(T)$ to be removed will be

$$
V_{s}(T)=W_{d}(T)-C
$$

In this way the sediment volumes to be removed are calculated as a function of the users water demand and water deficit situations which recur on average every $\mathrm{T}$ years. When $W_{d}(T)>C$ the sustainable useful capacity $C_{s}(T)$ will be

$$
C_{s}(T)=W_{d}(T)
$$

which could in many cases be significantly lower than the initial useful capacity and thus could result more sustainable from a technical, economical and environmental point of view.

\section{THE CASE OF CAMASTRA DAM}

The dam on the Camastra River, an affluent of the Basento River, in Basilicata (Italy) (Figure 2), has a basin of $344 \mathrm{~km}^{2}$ and multiple resource purposes. At the moment it has a silted up volume of more than $40 \%$ of the initial useful volume, and thus is in a state of extreme sufferance from this point of view. The Camastra dam was also chosen because of the availability of large quantities of reliable data including more than 40 years of inflows and water supplied volumes and data relative to at least 7 bathymetric surveys carried out in 13 years, with an average of a survey every two years which is practically unique in the Italian context.

In the case of the Camastra reservoir, the chronological reconstruction of the silting up process was achieved through an examination of the available bathymetric data as well as by means of a precise analysis of the reservoir hydrological management which led to obtaining data relative to the maximum silting up possible until 1988 [25]. As shown in Table 1 the current amount of silting

\begin{tabular}{|c|c|c|c|}
\hline year & $C\left(10^{6} \mathrm{~m}^{3}\right)$ & $V\left(10^{6} \mathrm{~m}^{3}\right)$ & V $\left(10^{6} \mathrm{~m}^{3} /\right.$ year $)$ \\
\hline \multirow[t]{2}{*}{1967} & 35.172 & 0 & \\
\hline & & & 0.333 \\
\hline \multirow[t]{2}{*}{1988} & 28.712 & 7 & \\
\hline & & & 1.392 \\
\hline \multirow[t]{2}{*}{1993} & 21.754 & 6.958 & \\
\hline & & & 0.489 \\
\hline \multirow[t]{2}{*}{1995} & 20.776 & 0.978 & \\
\hline & & & 0.328 \\
\hline \multirow[t]{2}{*}{1997} & 20.120 & 0.656 & \\
\hline & & & 0.087 \\
\hline 2005 & 19.421 & 0.699 & \\
\hline
\end{tabular}

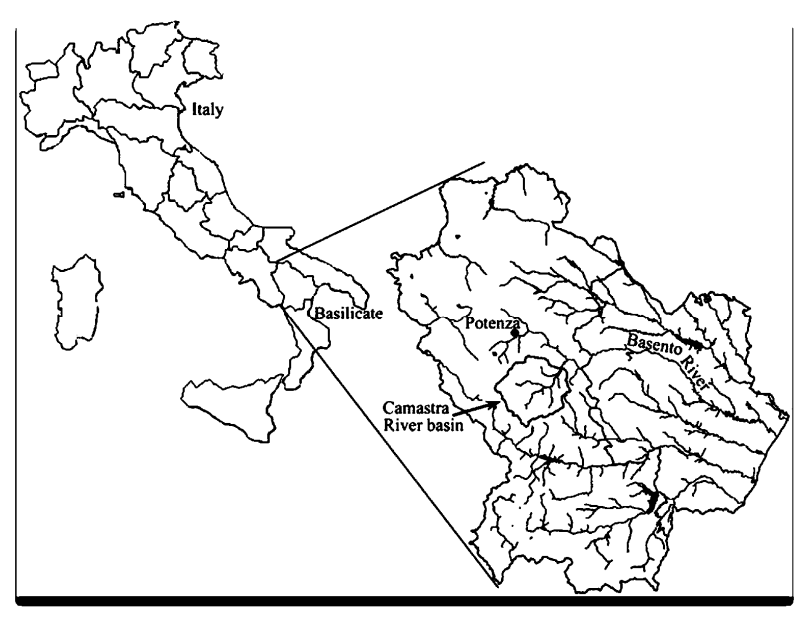

Figure 2. Camastra reservoir river basin.

Table 1. Temporal evolution of silting up in the Camastra reservoir. 
up $V$ in the Camastra reservoir is equal to about $16 \times 10^{6}$ $\mathrm{m}^{3}$ and the current useful capacity $C$ is equal to $19.421 \times$ $10^{6} \mathrm{~m}^{3}$.

As shown in [25] the average annual sedimentation rate $\mathrm{v}$ is really high between 1988 and 1993 due to superficial landslides confined on the Camastra reservoir right bank. After 1993, a progressive decrease in sediment supply to the reservoir had occurred because of the emptying of the landslides bodies and the effectiveness of river training works and soil conservation practices realized in the river network upstream the Camastra reservoir.

\section{APPLICATION TO THE CAMASTRA DAM AND RESULTS DISCUSSION}

The proposed methodology regarding the calculation of useful sustainable capacity was applied to the case of the Camastra reservoir. In the specific instance of the Camastra reservoir reference was made to a minimum ecological discharge of $100 \mathrm{l} / \mathrm{s}$, corresponding to a duration of 358 days on the duration curve with $T=10$ years.

As shown, for example, in the water balance carried out by means of the Eq.3 for a return period equal to 10 years (Table 2), the water emergencies period of the Camastra reservoir is from May to October and the deficit volume $W_{d}(10)$ is equal to $17.87 \times 10^{6} \mathrm{~m}^{3}$. Likewise, the deficit volumes with $T=15$ years and $T=20$ years are equal to $20.78 \times 10^{6} \mathrm{~m}^{3}$ and $22.40 \times 10^{6} \mathrm{~m}^{3}$, respectively.

As shown in Table 3, with the current useful capacity C estimated at $19.421 \times 10^{6} \mathrm{~m}^{3}$, it is possible to overcome water emergencies corresponding to return periods

Table 2. Camastra reservoir water balance from January $(\mathrm{J})$ to December (D) for $T=10$ years.

\begin{tabular}{cccccccc}
\hline & $\boldsymbol{I}$ & $\boldsymbol{U}_{\text {drink }}$ & $\boldsymbol{U}_{\text {ind }}$ & $\boldsymbol{U}_{\text {irr }}$ & $\boldsymbol{E}$ & $\boldsymbol{R}$ & $\boldsymbol{W}$ \\
\hline $\mathrm{J}$ & 3 & 1.002 & & & 2.68 & 2.68 & -0.68 \\
$\mathrm{~F}$ & 5 & 0.905 & & & 2.42 & 2.42 & 1.67 \\
$\mathrm{M}$ & 22.57 & 1.002 & & & 2.68 & 2.68 & 18.89 \\
$\mathrm{~A}$ & 12.74 & 0.969 & & & 2.59 & 2.59 & 9.18 \\
$\mathrm{M}$ & 6.15 & 1.002 & 1.607 & 0.572 & 2.68 & 0.50 & 2.47 \\
$\mathrm{~J}$ & 2.27 & 0.969 & 1.101 & 1.2 & 2.59 & 0.28 & -1.29 \\
$\mathrm{~J}$ & 0.48 & 1.545 & 1.533 & 2.702 & 2.68 & 0 & -5.30 \\
$\mathrm{~A}$ & 0.49 & 1.545 & 1.112 & 2.337 & 2.68 & 0 & -4.50 \\
$\mathrm{~S}$ & 0.96 & 1.496 & 0.931 & 1.698 & 2.59 & 0 & -3.16 \\
$\mathrm{O}$ & 0.61 & 1.545 & 0.65 & 0.082 & 2.68 & 1.94 & -3.61 \\
$\mathrm{~N}$ & 4.1 & 1.496 & 0.37 & & 2.59 & 2.22 & 0.01 \\
$\mathrm{D}$ & 9.49 & 1.002 & & & 2.68 & 2.68 & 5.81 \\
\hline
\end{tabular}

Table 3. Volume of sediments to be removed as a function of the return period.

\begin{tabular}{cccccc}
\hline $\begin{array}{c}\boldsymbol{T} \\
\text { (years) }\end{array}$ & $\begin{array}{c}\text { Water deficit } \\
\text { period }\end{array}$ & $\begin{array}{c}\boldsymbol{W}_{\boldsymbol{d}} \\
\left(\mathbf{1 0}^{\mathbf{6}} \mathbf{m}^{3}\right)\end{array}$ & $\begin{array}{c}\boldsymbol{V}_{s} \\
\left.\mathbf{( 1 0 ^ { 6 }} \mathbf{m}^{3}\right)\end{array}$ & $\begin{array}{c}\boldsymbol{C} \\
\left.\mathbf{( 1 0}^{\mathbf{6}} \mathbf{m}^{\mathbf{3}}\right)\end{array}$ & $\begin{array}{c}\boldsymbol{C}_{\boldsymbol{s}} \\
\mathbf{( 1 0}^{\mathbf{6}} \mathbf{m}^{3} \mathbf{)}\end{array}$ \\
\hline 10 & Jun-Oct & 17.87 & 0 & 19.421 & 17.87 \\
15 & Jun-Nov & 20.78 & 1.356 & 19.421 & 20.78 \\
20 & Jun-Nov & 22.40 & 2.976 & 19.421 & 22.40 \\
\hline
\end{tabular}

of 10 years; on the other hand the sediment volumes $V_{s}$ of at least one million and about three million cubic meters should be removed in order to overcome water emergencies corresponding to return periods of 15 and 20 years, respectively. The sustainable useful capacity $C_{s}$ is not so dissimilar from the current useful capacity $C$. If the useful capacity was restored, according to the Italian law requirements, to its initial value of $35.172 \times 10^{6} \mathrm{~m}^{3}$ it would be necessary to remove more than 15 millions of cubic metres of sediments from the reservoir bottom.

\section{CONCLUSIONS}

The proposed methodology regarding the calculation of useful sustainable capacity was applied to the case of the Camastra reservoir. In the specific instance of the Camastra reservoir reference was made to a minimum ecological discharge of $100 \mathrm{l} / \mathrm{s}$, corresponding to a duration of 358 days on the duration curve with $T=10$ years.

The proposed methodology is an instrument which allows the rapid quantification of the volume of sediment which is necessary to remove in changing scenarios, on the condition of access to adequate quantities of reliable bathymetric data; the scenarios are defined by:

- Return periods, which could, if necessary, be determined by a specific norm and which, as shown in the Camastra case, have a significant influence on the quantification of volumes;

- Water demand, which could remain unaltered or could be modified in the future on the basis of users' needs and political decisions, but also in the light of possible benefits/economic profits deriving from the utilization of the removed sediments.

This scientifically based approach could lead in many cases including, for example, that of the Camastra reservoir, to volumes of sediments to remove which are sustainable from a technical/economic viewpoint and also in environmental terms (methods of desiltation and relative impact on ecosystems downstream, final destination and reuse of sediments, etc).

\section{REFERENCES}

[1] Tomasi, L. (1996) Operation and maintenance problems due to sedimentation in reservoir. Proceedings of the In- 
ternational Conference on Reservoir Sedimentation, Fort Collins, 9-13 September 1996.

[2] De Vincenzo, A., Molino, B., Viparelli, R. and Albergo, G. (2003) Silting-up in reservoir: a risk and a resource. Proceedings of the 32nd IAHR World Congress, Venice, 1-6 July 2007, 2-10.

[3] Molino, B. (2003) Environmental protection in processes of reservoir restoration and use of sediments. Proceedings of the International Workshop from Watersheds Slopes to Coastal Areas: Sedimentation Processes at Different Scales, Venice, 3-5 December 2003, 2-11.

[4] Molino B. (2000) Combined Reservoir rehabilitation and sediment utilization: Economic defense. Proceedings of the International Conference on Trends in Water and Environmental engineering for Safety and Life, Capri, 3-7 July 2000.

[5] Valenti G., Bernardo G., Marroccoli M. and Molino B. (2003) Beneficial reuse of reservoir sediment in the cement industry. Proceedings of the International Conference on Remediation of Contaminated Sediments, Venice, 2003.

[6] Tamburino, V., Barbagallo S. and Vella P. (1989) Indagine sull'interrimento dei serbatoi artificiali siciliani. Ingegneria Agraria, 3, 156-164. (in Italian)

[7] Bazzoffi P. and Vanino S. (2009) L'interrimento degli invasi ad uso irriguo nelle regioni meridionali: Rilievi diretti metodologie e modellistica. Rapporto INEA. (in Italian)

[8] Gumbel, E.J. (1941) The return period of flood flows. The Annals of Mathematical Statistics, 12, 163-190.

[9] Davie, T. (2003) Fundamentals of hydrology. Routledge, London and New York. doi:10.1002/(SICI)1099-1085(199608)10:8<1021::AIDHYP407>3.0.CO;2-I

[10] De Roo, A.J.P. (1996) LISEM: An introduction. Hydrological Processes, 10, 1021-1025.

[11] Linsley, R.K., Kohler, M.A. and Paulhus, J.L.H. (1982) Hydrology for engineers. Mc Graw-Hill, New York.

[12] Bovee K.D. and Milhous, R. (1978) Hydraulic simulation in instream flow studies: Theory and techniques. Instream Flow Information Paper 5, Cooperative Instream Flow Service Group, Fort Collins.

[13] Binns, N.A. and Eiserman, F.M. (1979) Quantification of fluvial trout habitat in Wyoming. Transactions of the American Fisheries Society, 108, 215-228. doi:10.1577/1548-8659(1979)108<215:QOFTHI $>2.0 . \mathrm{CO}$ $\underline{2}$

[14] Nelson, F.A. (1980) Evaluation of selected instream flow methods in Montana. Proceedings of the Annual Conference of the Western Association of Fish and Wildlife Agencies, Montana, 13-17 July 1980, 412-432.

[15] Bovee, K.D. (1982) A guide to stream habitat analysis using the instream flow incremental methodology. Instream Flow Information Paper 12, USDI Fish and Wildlife Services, Office of Biology Services: Washington DC.

[16] Mosley, M.P. (1983) Flow requirements for recreation and wildlife in New Zealand rivers: A review. Journal of Hydrology, 22, 152-174.

[17] Cavendish, M.G. and Duncan, M.I. (1986) Use of the instream flow incremental methodology: a tool for negotiation. Environmental Impact Assessment Review, 6, $347-$ 363. doi:10.1016/0195-9255(86)90027-2

[18] Tyus, H.M. and Karp, C.A. (1989) Habitat and streamflow needs of rare and endangered fishes, Yampa River, Colorado. US Fish Wildlife Service Biological Report 89.

[19] Orth, D.J. and Leonard, P.M. (1990) Comparison of discharge methods and habitat optimization for recommending instream flows to protect fish habitat. Regulated Rivers: Research and Management, 5, 129-138.

[20] Stalnaker, C.B., Bovee, K.D. and Waddle, T.J. (1996) Importance of the temporal aspects of habitat hydraulics to fish population studies, Regulated Rivers: Resource and Management, 12, 129-138.

[21] Copertino, V.A., De Vincenzo, A., Viparelli, R. and Telesca, V. (1997) The influence of fluvial morphology on minimum instream flow. Proceedings of the 27th IAHR Congress, San Francisco, 10-15 August, 258-267.

[22] Jowett, I.G. (1997) Instream flow methods: A comparison of approaches. Regulated Rivers: Research and Management, 13, 115-127.

doi:10.1002/(SICI)1099-1646(199703)13:2<115::AID-R $\underline{\mathrm{RR} 440>3.0 . \mathrm{CO} ; 2-6}$

[23] Tharme, R.E. (2003) A global perspective on environmental flow assessment: emerging trends in the development and application of environmental flow methodologies for rivers. River research and Applications, 19, 397-441. doi:10.1002/rra.736

[24] Shang, S. (2008) A multiple criteria decision-making approach to estimate minimum environmental flows based on wetted perimeter. River Research and Applications, 24, 54-67. doi:10.1002/rra.1047

[25] Molino, B., Viparelli, R. and De Vincenzo, A. (2007) Effects of river network works and soil conservation measures on reservoir siltation. International Journal of Sediment Research, 22, 273-281. 